«Keruen» scientific journal

M.O.Auezov Institute of Literature and Art

ISSN 2078-8134

Volume 1, Number 70 (2021)

https://doi.org/10.53871/2078-8134.2021.1-05

IRTSI 398(4/9); 801.8(419)

\author{
Gulnaz Dautova \\ Al-Farabi Kazakh National University, \\ Almaty, Kazakhstan \\ e-mail: gulnazdautova001@gmail.com
}

\title{
PECULIAR OF HEROES OF KAZAKH HISTORICAL EPIC
}

\begin{abstract}
The article defines the image of a defender-hero in the historical epics of the Kazakh people. In the historical poems, the character of "defender - hero" is portrayed in different ways. Usually main hero's prototype is a real person that lived in particular region around that time. We can say that historical epic's characters are realistic and conditional. It is known that they act within historical events, but at the same time being able to serve in epics legislation. As we can see from the poems, he was a mentor and educator who gathered around him a brave young man. From "defender hero" he has transformed into a heritage of character that cares his people. Young heroes close to Khan even though how valiant they never refuse take advice given by senior hero and do as they say, we can clearly understand their unity to keep peace by protecting people and their country from menace and danger. Because of such heroes were the protectors of our Kazakh nation we could withstand all kind of misfortunes and dangers and survived. Heroes did not just own the great steppe they also prevented it from all sort of menace. In historical epics, it is evident that the heroes served all their life during unstable and difficult times, when they did not manage to resolve their own personal problems.

In addition, the psalms belonging to the historical epic genre of Kazakh folklore, which we are considering, are diverse. In all of them honored portrait of hero that served his country. However, according to the purpose and the main theme of the epos, we have noticed that the "defender-hero's" personality image is different.
\end{abstract}

Keywords: folklore, kazakh epos, historical epic, Golden Horde, defender-hero, image, prototype

Introduction. In Kazakh folklore, the genre nature of the historical poem has always been determined and scientific views on the laws of its development have been steadily maintained. Thus, in the course of development of Kazakh folklore, it was determined that historical epos had changed from the ancient form of epic genre to a new one, indicating its closeness to reality.

One of the common features of all eposes - if it is far from the described historical events, the more shriveled it is to history, general terms instead of solid facts, instead of describing specific events, they begin to show common typical events of a certain era, the actual historical events start to become typical event. Ultimately, the creation of real-life events transforms into a general picture of the typical events of a certain era. This process is characterized by the fact that all Kazakh, Kyrgyz, Altai epic traditions are more developed, it is clear from oral folk literature. These laws are proved in the views of E.Ismailov (Ismailov,1967) he analyzed the scientific foundations of historical songs and historical poems. The scientist clarifies the features of the historical poems as a genre, and chronologically analyzes the works of historical poems. 1) XVIII century, 2) XIX century, 3) compositions of the XX century. Author pays special attention to the works that he recommends, especially the ones that were born in the end of 19th century and the beginning of 20th century (Ismailov, 1967,P.122). 
E. Tursunov, a scientist who has developed a profound conclusions about historical poetry: He concludes it as follows - "What we call as a historical poem (junior epos) - which has not yet been completely eradicated in the minds of the people, in some cases has been followed by historical events. Also it has used poetic techniques that were used in ancient heroes poetical language to describe historical events and became a sample of oral literature. Junior epos is a "intermediate genre type" between historical epos and historical poems" (Tursynov,1979, P.87).

On the basis of new scientific laws in the period of independence, the scientist B.Azibaeva studied the ways of development of the epos and summed up the detailed conclusions on the originality of the historical epos. "All subject matter and plot, general poetics, are devoted to the events of different historical periods and are made up of one genre, but it is internalized to the genre (for example, real-historical). Historical poems also appear in the frames of the heroic epos, with its general similarities and with a number of differences, namely the almost all historical poems have identical real historic prototype of the heroes, the heroes are not over praised as in the eposes, the point of visualization is not the epic destiny of the hero, but rather a place in the history of the people. Historical poems depict historic events in different regions of Kazakhstan in the XV-XVIII and XIX-XX centuries." (Azibaeva, 2014, P.136) The complex events that our people experienced in several epochs in historical poems: Golden horde, events during Kazakh Khanate, Kalmyk, the Dzhungar invasion, the attacks of the Kokand, Khiva khanates and Kyrgyz manas, along with the military campaigns of the Russian Empire on a regular basis for the purpose of radicalization of the Kazakh land and etc. are displayed.

Historical poem, which is one of the branches of the Kazakh epos, is a genre different from other genres of Kazakh folklore in terms of its fraternity to history. In the history of folklore studies, it has developed various scientific conclusions on the recognition of its genre nature.

For example, for the first time Sh.Ualikhanov separated historical poem as individual genre as it reflects the events that have taken place, which did not disappear from people's memory, (Ualikhanov, 1985,P.282) he commented that historical poem has the involvement to history from ancient times, while M.Auezov (Auezov, 2001, P.171) described it as "type of heroic epos of the post-modern era" and differentiated some genre signs. We can see his basic principles on the historical background of the common epos can be summarized by his words: "When we look at Kazak hero tales from the beginning until the end, we can't tell that it fully opens the curtain of significant historic events but it lets us at least peek through key hole. We all well known how much melody of oral story helps to form our history. Heroes in most of the old stories are not born from our ancestors' imaginations they are based on real heroes that existed" (Auezov, 2001, P. 68-69).

M.O. Auezov describes the characteristic features of historical poem as follows: The story of the historical poem are the historical event that has been evident in the history of the country; People who have been involved in real events of historical poem have different situations and the general nature of the people 's interests; The main heroes of the historical poem are well known, famous and respected people of the country; Historical stories are mainly based on those events, and the reality is overwhelming because they have been seen by eyewitnesses. M.O. Auezov: The story of a Ahtaban Shubirinda in Kazakh history which occurred because of kalmak massacre and Russian colonial yoke, the loss of Kazakh nations freedom and liberty was described as "heads down in halter, unbroken were broken, giants held down". The scientist points out that the Kazakhs, as a historic phenomenon had to surrender to Russians it was by unfairness of the Kalmyks and the long bloody massacre, were the result of the Central Asian khans' pressure and the outrage of the Kazakhs. Thus, the Kazakhs, who were under exerting pressure the Russians colonists for their own purposes, easily persuaded them. (Auezov,2001,P.147).

Methodology. Currently the researchers have proved typological commonness of the most narrative and thematic parameters of epics of different nations. This means that the ideologicalthematic and plot-motivative range of the Kazakh epic, as well as other ethnic epics, as a whole, is correlated with the "catalog" of the world epic fund. But this Kazakh epos (and any other epos) is a unique, original creation of ethnic group whose uniqueness is due to complex causes and due to the features specific historical circumstances of epic art. This means that in the epic field of Kazakh 
ethnos typologically common themes and motifs are developed in a specifically national way, which results in the widest variety and diversity and is actually a kaleidoscope of infinite variants of implementation and the possible interpretations of these categories, i.e. the national specificity of the epic is formed.

We should mention with gratitude and respect the names of the researchers who made a great contribution to the study of the Kazakh epic, they are: Ch. Valikhanov, V.V. Radlov, G.N. Potanin, A.Divaev, I.N. Berezin, A. Baytursynov, Kh. Dosmukhamedov, A. Bokeikhanov, M. Auezov, S. Seifullin, A. Margulan, K. Zhumaliyev, N.S. Smirnov A.Konyratbaev, R.Berdybayev, T.Sydykov and others. The works that have been created in the last decade of the XX century and at the beginning of the XXI century are also very important for the study of epics. They are monographic study of such authors as: O.Nurmagambetova, Sh.Ibrayev, B.Azibaeva, E.Tursynov and S.Kaskabasovs works written by him for the collections. Great literature is devoted to the genre classification of the Kazakh epic. These are the works of A. Margulan, S. Sadyrbayev ("Issues of the cyclization of the Kazakh epic", Alma-Ata, 1965). The problems of historicism became the main theme of N.Silchenko's research. The problem of the epic storyteller is a constant object of the research (see A.Margulan's works "About the carriers of the ancient poetic culture of the Kazakh people", E.Tursynov's monograph "Types of carriers of the Kazakh folklore", a series of works by E.Ismayilov about akyns, etc.). The works of some outstanding storytellers - Dzhambul, Bayzakoa, Nurkhan Ahmetbekov (the works of M. Auezov, I.Eventov, S. Esipov) are considered in detail. On the epic problems, a number of Ph.D. thesis have beendefended - S.Neghimov, A.Ospanov, J. Bekturov, B.Abylkasimov and others. The works of S. Satpayev illuminate the problems of the Kazakh epic ties with the epic traditions of the East in the literary aspect.

For our research, B.N. Putilov's monograph called "Methodology of comparative-historic studying of folklore" is very important. (Putilov, 2009) In this work the author has revealed the essence of historical-typological research. The research was based on the theoretical conclusions of leading scientists, including foreign researchers who conducted important research in the Kazakh literary science. In particular, V.M. Zhirmunskii "National heroic epos", V.Ya. Propop «Folklore and reality», B.N. Putylov «Heroic epos and reality», E.M. Meletinsky, "The Advent of the heroic epos", J. Campbell, "Thousand-faced hero", F. Urmancheev "National heroic epos", Sh.Ualikhanov " Selected works", M.Auezov "History of literature", A.Margulan, K.Zhumaliyev, A.Konyratbayev, M.Gabdullin, R. Berdybaev " Ideology of Epos", Sh. Iibirayev "World of Epos", S. Kaskabasov "Kazakh folk prose", B. Abylkasymov "Telqonir", O. Nurmagambetova "Kazakh heroic epos", E. Tursunov "The study of historical poems and nature of genres", B. Azibayeva "The plot of the Kazakh eposes" and etc. as well as theoretical concepts and basic concepts of domestic scientists.

Theory/calculation. In the historical epic, for many times during the tragic events of the Kazakh people, which had been the result of continuous aggression of the $\mathrm{XV}-\mathrm{XX}$ centuries, courageous heroic spirit is manifested. United hero and nation, for their country and land the vigorous courage in the struggle for freedom is described.

In historical epics, images are not imaginary, courageous historic personalities who are indifferent to the interests of the people and the state, the heads of the Kazakh state - the khan and the sultans, the commanders of the military, the image of the famous people and warriors, distinguished by heroism and military talent. Almost all characters of historical poems are real people, their images are not as distinct as heroic epics; more precisely, all the characters in the event are described as in ordinary everyday life.

The historical character of the historical epic is different from the heroic epic. Here a real story is often based on real life events. That is why the compilation of stories consists of wellknown events of the Kazakh steppes - known events that can be estimated in approximately a certain area. Moreover, there are not much frivolous fantasy characteristics. The event also ends in line with reality. However, preserving heroic spirit, it inherits a new kind of historical epoch, linking the ancient heroism and heroic epic tradition with history and creates new image.

Historical poems became complex only after heroic poems so there are typical character differences. 
The scientist B. Azibayeva concludes that historic wonders are figuratively describing various historical events and historical persons of our nation in the past centuries. They are conditionally described as "Historical epics, characterized by events in on the territory of Kazakhstan and China during XIX century and the first half of the XX century" were divided to 2 groups of historical poems, the national liberation struggle in China, the internal enemy - the resistance to kuomintang, the justice of the interethnic inequality and power and the struggle for social equality. However, since the poems belonging to this group are specially considered in the form of other research, we have just acquired the poems on the territory of Kazakhstan and took as a basis of our dissertation.

Differing old and new thoughts about the epics, the scientist B. Azibaeva according to the latest laws of folklore science shows that historic poems, representing various historical events, are emerging in the tradition of heroic epic tradition and have the similarities and peculiarities of genre: "1) The form of depiction in historical poems is not the epic destiny of the hero, but the place of the history of the nation, the battle of the most important ordinary soldiers, the warriors, the khan and the military commanders; 2) the prototype of almost all historical heroes, in other words, they are known by history, have served their nation they are - soldiers, commanders, courage soldiers, hero soldiers; 3) Historical epos characters are not particularly praised as heroic epos heroes, their images and characteristics generally correspond to the standard of life of ordinary people, and more precisely, all the characters participating in the event are described as everyday life. "(Azibayeva, 2016, P.71) Bearing in mind these scientific principles in the history of the epic, the object of our research was to analyze the types of historical poems, showing different stages of development, and to consider it on the basis of three big contingencies.

- The type of heroes who fought against the Dzhungar invasion of the XVIII century.

- Heroes who protected the people from colonial aggression

- Defenders of the Central Asian from invaders

Thus, the conditional differentiation of opinion was reflected in the question of how the personality of "Defender - Hero" was formed.

Results. As a result, during the last 300 years since XI century there were many historical events in the history of the Kazakh nation. Although not all of them are the same, the difficult moments that have had a significant impact on the country's destiny have been reflected in historical ghosts and have come from generation to generation. It has been politically blocked for a long time because it has been based on some poetic stories not only of great history, but also because it is closely related to the heroic history of the nation. It is possible to speak about it only in light of modern requirements.

The historical epos differs from the linguistic and artistic means. There are not such characteristic of extermination and mythic images, as in ancient epic heroic eposes. The visual aids also reflect the realities of real life. In addition, geographical summaries are more commonly referred to as to the real place names were the historical event occurred. Thus, we have seen that the historical epos has many similarities with other epic genres as well as their similarities with the "defender-hero" image.

Kazakh epic work is an integral part of the spiritual culture of the people and goes back to its antiquity. Throughout its history from the era of consolidation of the disparate tribes of nomads of single monolithic Kazakh nation to its heyday in the era of mature socialism - the epic of Kazakhs carried the most important moral and aesthetic values, worked out by the people, repulsed all the major turning historical events, becoming a true chronicle of its spiritual, social and material life. The brightest examples of the Kazakh epos became an integral part of the world culture.

Epic tradition of Kazakh people is actively operating in our days, thus proving the possibility and the organic existence of such ancient heritage in the framework of socialist culture. The vividness of the epic tradition in Kazakhstan makes topical task of reviewing its nature and its processes of functioning and transformation in the present.

It is clear that, firstly, the Kazakh epos was formed long before the formation of the Kazakh nation and, secondly, it is the part of a hierarchical system of the highest order and genetically associated with each of its levels. In the most general terms, this hierarchy is as follows: epic of 
Turkic people, epic of people of Central Asia and Kazakhstan, Kazakh epos and folklore, epic and local traditions of the Kazakhs, story teller schools within each epic tradition, the individual features of the narrators within a single school, etc.

The study of the Kazakh epos has its own history and established strong traditions. None of the researchers of folk art of the Kazakh people ignored this outstanding artistic phenomenon. The subject matter of compositions of the most common scene legends has been fundamentally studied, the initial classification of the genre of epic works has been made, its poetics, language, history, formation and main stages of evolution are being studied. The problems of historicism of the Kazakh epos have been thoroughly developed.

As it is known, in the scientific search its prerequisites are highly important. Any statement of folklore facts is based on expectations, not always fully conscious. Therefore, any description of the material and its interpretation may not be completely free of subjectivity. The accumulation of new facts inevitably corrects the theory itself and puts forward on this basis, new assumptions, which are tested for viability, and any correction of representations, in our view, is positive, even if it was not enough.

However, when dealing with the living cultural phenomenon which is subject to transformation, the researcher does not have an opportunity to expect passively the emergence of some kind of theory that can bring perfect order, based on slowly collected and systematized facts and phenomena. A hundred times more topical becomes the task of collecting and understanding of the epic traditions of the Kazakhs, which reveals a great moral potential which is able to participate in the modern spiritual life of the Soviet people.

Discussion. Defender from colonial yoke of Russian Empire. In the history of the Kazakh people in the XVIII century there were fierce battles for the destiny of the Kazakh Khanate took place. Particularly, several stormy Jungars invasions caused the country to suffer greatly. But with the help of wise Kazakh leaders and the brave warriors managed to overcome the enemy and retain their country. These troublesome times have become a glorious historical epoch of the khan-batyrs, the sultans, who have not only been able to capture heroes and fortune-tellers, but also have a courageous heroism was praised.

It is well-known that the character image of the heroic countrymen in epic art is transformed to each historical period. Sh.Ibrayev said: "There is a great difference between the heroic epic epoch and the hero who were in life. In the end, as the social relationships changed, the notion of "hero" changed. Only a heroic person who combines his work with a socially high purpose becomes the root of an epic poem, a hero of the heroic era, "- (Ibrayev,1993, P. 219-220) that the khan was a social type, which got united with the persona of a hero. That is to say, the hero persona of the heroic epic is transformed into historical poem, and it begins to possess qualitative qualities. Because the epos became closer to the realities of life rather than artistic imagination. From the men, who had heard the message of the coming enemy and rode the horseback they count not only with their country but also with the people of the country. In this context, folklore's motive of "fair king" is in the nature of poetry. He is now the hero of the power, who holds the authority of the whole country, in addition to his heroic deity. "The image of Hero Khan is formed with the period when the fragmented tribes became the nation. Its activity is based on the idea of unity, the history of the country's history, "Shibek Ibrayev [6, 219-220] he took W.Y.Propp's opinion as a base. The appearance of the scientist "batyr khan" has become a social cause of sequencing (cycling), but also to widely comment on the idea that it would be proud of it.

Heroes who fought for the future of their people without leaving to the enemy's hand piece land of the Kazakh nation have pledged to the descendants of the enormous land starting from Altai until Atyrau. Before the eighteenth century, the Sacred World, which began from the time of the Hun, did not stop at the end of the twentieth century, the great spiritual force which did not stop in our holy land. Zhauzhurek batyrs, fighting with "white spine, with a white spear", struggled to fight for today, leaving the pine forests, our homeland. That is why the image of "defender-hero" in historic poems is primarily reflected in the heroic image. This is an example of the different character of Ablai's image as a defender of the historical poems of Ablai. 
Sh.Ibrayev thinks that the type of "wise hero" is not very common and formed later. (Ibrayev, 1994, 273) The image of the famous heroes serves as an ideal for the people to show them as an orator. That is why the hero defending the country is not only showing the people as a believer, but also by introducing oratoric words to look wise. The outstanding example of the historical person is Syrym batyr. Folk tradition, despite the fact that many people speak commonly, but only to Syrym, could answer to the question of the Khuwa khan is in the best interests of the Kazakh nation reflects his reputation in solving international issues.

In the 19th century, there were not few heroes who were struggling for freedom and fighting against the injustices of the ruling elite and openly fighting for the freedom of the nation. Their names were praised in historical songs and reached the next generation. The heroism shown by Syrym batyr on the way of uniting the power of the Kazakh people against the colonial oppression arose from his compassion and love for his nation. "The Tsarist government began with the removal of the traditional state structure in the Kazakh steppes by the crisis of the Young Zhuz government based on the introduction of the administrative reform of Orenburg governor Ogeldy Igelstrom. In general, the Russian Empire has pursued a policy that has consistently overtaken Kazakhstan's political independence. Syrym Datovich, who opposed the strict arbitrary order of the Cossacks of the Russian Orthodox Church, who had been implementing the colonial policy of Russia, defended his nation from colonialism and opposed the extradition to the Kazakh villages. In the historical memory of "Syrym batyr", which describes the heroic heroism defending the country, his courageous heroism and accompanying political skills are recognized. It did not give in to the actions of the authorities who wanted to use their money and power, but they were closer to the people. His purpose was to destroy the hypocritical rulership of the people and to establish a new government of the country. He wanted the people of his land to be happy.

In the difficult moments of the country's life, the people who trusted in the sincerity of Syrym recognized him as the leader, and Sirim's reputation was more than the khan. The mentality and actions of the people of the intrinsic confrontation of the people will heighten his personality as a universal hero. The hero and the prominent person turned the conspiracy of the Kazakhs into civil war. The hero, who considers it necessary to save two-sided exploitation, not only manages the national liberation struggle, but also repeatedly wrote letters to the governor-general without hesitation on the way to improving the welfare of the people.

The true dream of Syrym was to get out of the grave of the Kazakh people and reach the rank of independent country. Of course, it was impossible during the historical period of Syrym's life. Nevertheless, the hero was able to protect his nation from the threats of his own destitution. In the poem, the dream is to dream of independence of the people, the desire of the Kazakh nation to be free, and hope that nation would stand up for the sake future of their country.

Defenders of the Central Asian Invaders - Heroes: During the 30s - 60s of the XIX century the Kazakh people also experienced the tyranny of Khiva and Kokand khanates. Heroes who fought against Russian colonialism and the overwhelmingly populous heroes resisted. Historical poems about Dzhankozha batyr, who started to lead the country, were characterized by the despair of Khiva, Kokand's oppressive tax, violence, colonialism of Russian colonialists, as well as those of an outsider who introduced them into the country and deported their country into an enemy. Jokozhabatyr, the legitimate heir of epic defenders before him, which allowed the people to liberate their freedom, first of all, was the only thing that was done by the husband. His property given to his people is reflected in the blood of the ancestors with the blood of his father. In his poems, Dzhankhozha's father is honored as the wise man who could divide single hair equally, also he wishes his son to be a sacrifice in the name of unity.

Having read several versions of the "Zhangozha Batyr", it is evident that from the very first enemy's departure, the heroic and organizational talent in the people's uprising in various years against the occupation of the Kokand, Khiva, Bukhara khans in the Kazakh land and the colonial rule of the Russian Empire you can imagine the full picture of its events.

In the poem version, Zhanghozha alone is described as a hero who has been the only soldier that could fight back the great Russian king. Generally, Zhankozha batyr tells about the unity and 
solidarity of the people in poem, which is one of the most important conditions in the country. In all versions of the epic about Zhankozha batyr, the justice and heroism is connected with the dreams of the people.

It is known that the Dzhungar and the Kazakh Khanate war ended with the victory of the Kazakh in the third quarter of the XVIII century. But Kalmyk's objection did not immediately shake. Especially in the border areas, the Kalmykia's fugitive slaughtered acts, various conflicts with the Kazakh hands have been portrayed in historical monuments. An armed group of the Kalmyk durbet and urankhay tribal troupe threatening the Kazakh people in the first half of the XIX century is clearly reflected in the poem "Myrzash batyr". The looting of the Kalmyk tribes in Zaisan, Tarbagatay, Markakol and the people of Myrzash and the end of the massacre of the people in the captivity of a peaceful country is a matter of national interest. Myrzash batyr, who frees his holy land from the aggressor and rescues the deserted people, is ready to sacrifice all his conscience to patronize the people and patriotism. In heroic combat, traditionally heroes win. Myrzash batyr is a hero of historical genre, and every step of his way is accompanied by the data.

The nature of the poem belonging to the historical epos genre of Kazakh folklore we have considered is different. Everyone is honored with the image of the heroes of the country. However, in accordance with the purpose and the main theme of the poem, we have noticed that the personality of the defender - hero is different.

Conclusion. During the research, the following conclusions on the nature of the historical poem, based on historical events in Kazakhstan, were summarized.

First of all, historical epos is more realistic than other types of epic in describing the events that have taken place in the near past. Because heroes have a prototype, and those who have witnessed the story are spreading it. The talented poem singers was able to reproduce and revive the history of the country's fortress, which had been seen by the eyes of men or by the spectators. In the strong epic tradition, the words of such famous poem singers were widely circulated and taught by the general public. That is why historic poems are not just a story of history or historical personality, but the desire of the nation - the story of the people that is in harmony with the interests. For the country, dignity was given to the country by raising its heroes with their enemies. It is characteristic to the heroic heroes of historic heroes who have become the heroes of historical monuments, reflecting historical events in Kazakhstan: Protecting peace in the country, protecting the homeland from foreigners, and united in the ideals of the liberation of the people.

In the historical poems, the type of "defender - hero" is different in different ways. For example, Bogenbay batyr's heroic moment in the flames of the heroic movement, with the young heroes, is dominated by a masculine, brave masculine image. But in the opening words and introductions of the pagan, he remembers the heroic deeds that he has waged against the enemy for over 40 years, thus answering the question of how the next generation of high-ranking reputation and wisdom, established in the Kazakh language, defending the country, the defense of the country ". And Kabanbai in historical poems is distinguished by the heroism of the battle. He is even more distracted by the hero's "guardian-heroine" than his heroic fight against the enemy. Sirim defends the countrs and land which brings him closer to the heroes of the epic, saying, "He is a warrior who could enter the palace and face the king face-to-face." All of these questions show that the actions of the "defender" are different in different historical periods. For example, in one variant of "Soranki batyr", he is looking for a land of happiness, salvation for the people of Suransh. Behind the scenes in search of happiness from the outside, he shows history of the fate of the native land is under pressure.

The historical epos differs from the linguistic and artistic means. It is characteristic of extermination and mythic images, as in ancient epic heroic epos. The visual aids also reflect the realities of life. And geographical summaries are more commonly referred to as the historical events of the historical event. Thus, we have seen that the historical epos has many similarities with other epic genres as well as their similarities with the "defender-hero" image. 


\author{
Даутова $\Gamma$. \\ Әл-Фараби атындағы Қазақ Ұлттық Университеті, \\ Алматы қ., Қазақстан \\ e-mail: gulnazdautova001@gmail.com
}

\title{
ТАРИХИ ЭПОСТАРДАҒЫ «ҚОРҒАУШЫ-БАТЫР» ОБРАЗЫ.
}

Андатпа: Мақалада қазақ халқының тарихи эпостарындағы қорғаушы батыр образы, қызметі нақтыланды. Тарихи жырлардағы «қорғаушы - батыр» типі әр түрлі сипатта көрініс табады. Тарихи эпостың кейіпкерлерінің прототиптері көбінесе белгілі бір аймақта өмір сүретін адамдар болып табылады. Тарихи эпос кейіпкерлерінің образдарын шынайы, сонымен қатар шартты деуге де болады. Олар көпшілікке белгілі тарихи оқиғалар аясында әрекет ете жүріп, сонымен бір мезетте эпикалық заңдылыққа сай қызмет етеді. Сонымен қатар, біз қарастырып отырған қазақ фольклорының тарихи эпос жанрына жататын жырлар табиғаты әрқилы болып келеді. Барлығында да ел қорғаны болған батырлар бейнесі дәріптеледі. Бірақ жырдың мақсаты мен негізгі тақырыбына сәйкес «қорғаушы-батыр» тұлғасының да әр түрлі көрініс беретіндігін байқадық. Осының барлығы эпикалық дастандардағы бір ғана батыр образы, бас қаһарман бейнесі арқылы ашылып отырады. Бастысы ол қашан да елін, жерін, сүйікті жарын жатжұрттық басқыншылардан қорғаушы болып келеді.

Қазақ фольклорында әр кездерде тарихи жырдың жанрлық табиғаты айқындалып, оның даму заңдылықтары жөнінде ғылыми пікірлер тиянақталды. Сөйтіп, қазақ фольклорының даму барысында тарихи жыр эпикалық жанрдың ежелгі формасынан жаңа сипатқа көшкенін, оның шындыққа жақындай түскенін көрсететін бір саты екені айқындалған.

Кілт сөздер: фольклор, қазақ эпосы, тарихи жыр, Алтын орда, қорғаушы батыр, образ, прототип

Даутова $\Gamma$.

Казахский национальный университет им. аль-Фараби, г. Алматы, Казакстан

e-mail: gulnazdautova001@gmail.com

\section{ОБРАЗ ЗАЩИТНИКА БАТЫР В ИСТОРИЧЕСКИХ ЭПОСАХ.}

Аннотация. В статье рассматривается роль защитника в исторических эпосах казахского народа. В исторических эпосах тип защитник - батыр имеет различный характер. Они действуют в рамках известных исторических событий, одновременно в соответствии с эпическими закономерностями. Прототипы героев исторического эпоса зачастую являются людьми, жившими одновременно в определенном регионе. В то же время жанр исторического эпоса в казахском фольклоре разнообразен. Во всех эпосах олицетворяется образ героев, которые защищали страну. Но мы заметили, что в соответствии с целью и основной темой эпоса, и тип «защитник-батыр» представляет собой разнообразную картину. Все это раскрывается образом одного героя в эпических дастанах, образом главного героя. Главное, что он всегда защищает страну, землю, родных от джунгарских захватчиков.

А так же, расматривается что в казахском фольклоре в разное время была выявлена жанровая природа исторического произведения, изучены научные мнения о закономерностях его развития. Таким образом, в процессе развития казахского фольклора было определено, что историческая поэзия с древней формы эпического жанра перешла на новый характер, она приближается к реальности.

Ключевые слова: фольклор, казахский эпос, исторический эпос, Золотая орда, защитник батыр, образ, прототип 


\section{Information about authors:}

Gulnaz Dautova, Al-Farabi Kazakh National University, Almaty, Kazakhstan, gulnazdautova001@gmail.com

\section{REFERENCES}

[1] Azibaeva B. (2014) Plots of the Kazakh epic. Almaty. (kaz)

[2] Azibaeva B. (2016) The Kazakh Epos. Dominant and constants of plot-motivational background. Germany. (rus)

[3] Auezov M.O (2001) The history of literature. Almaty. (kaz)

[4]Valikhanov Ch.Ch. (1985) Sobr. Cons. In 5-th volume. Volume 5. Almaty. (rus)

[5] Ibrayev Sh. (1993) Epos world. Almaty.(kaz)

[6] Ibraev Sh. (1994) Poetics of the Kazakh poems. Almaty. (kaz)

[7] Ismailov E. (1967) In the newest look. Alma-Ata. (kaz)

[8] Putilov B.N. (2009) Methodology of comparative-historic studying of folklore. Moscow. (rus)

[9] Sadyrbayev S. (1999) Issues of the cyclization of the Kazakh epic. Almaty. (kaz)

[10] Tursynov E. (1992) The study and genre character of historical pearls. Almaty. (rus)

\section{ӘДЕБИЕТ}

[1] Әзібаева Б. (2014) Қазақ эпосының сюжеттері. Алматы. (қаз)

[2] Әзібаева Б. (2016) Қазақ эпосы. Доминат және сюжеттік-мотивациялық фон константтары. Германия. (орыс)

[3] Әуезов М.О. (2001) Әдебиет тарихы // Мұхтар Әуезов. Шығармаларының елу томдық толық жинағы. 4-том. Зерттеулер, окулықтар, әдеби нұсқалар. Алматы. (қаз)

[4] Уәлиханов Ш.Ш. (1985) Шығармалар жинағы. Том 5. Алматы. (орыс)

[5] Ыбыраев Ш. (1993) Эпос әлемі. Алматы.(қаз)

[6] Исмаилов Е. (1967) В поисках нового. Алма-Ата. (рус)

[7] Путилов Б.Н. (2009) Фольклорда салыстырмалы-тарихи талдау әдіснамасы. Мәскеу. (орыс)

[8] Садырбаев С.С. (1999) Қазақ эпосының циклизация мәселелері. Алматы. (қаз)

[9] Тұрсынов Е. (1992) Тарихи жырлардың зерттелуі мен жанрлық сипаты// Қазақ тарихи жырларының мәселелері .Алматы. (қаз)

\section{ЛИТЕРАТУРА}

[1] Азибаева Б. (2014) Сюжеты казахского эпоса. Алматы. (русүказ)

[2] Азибаева Б. (2016) Казахский эпос. Доминанты и константы сюжетно-мотивационного фона. Германия. (рус)

[3] Ауэзов М.О. (2001) История литературы. Алматы. (каз)

[4] Валиханов Ч.Ч. (1985) Собр. соч. в 5-ти томах. Алматы. (рус)

[5] Ибраев Ш. (1993) Мир эпосов. Алматы. (каз)

[6] Исмаилов Е. (1967) В поисках нового. - Алма-Ата. (рус)

[7] Путилов Б.Н.(2009) Методология сравнительно-исторического изучения фольклора. Москва. (рус)

[8] Садырбаев С.С. (1999) Вопросы циклизации казахского эпоса. Алматы. (каз)

[9] Турсунов Е. (1992) Изучения и жанровые описания исторических эпосов. Алматы. (рус) 